\title{
Correction to: Spatio-temporal graph convolutional neural network for remaining useful life estimation of aircraft engines
}

\author{
Mengni Wang ${ }^{1}\left(\mathbb{D} \cdot{\text { Yuanxiang } \mathrm{Li}^{1} \cdot \text { Yuxuan Zhang }}^{1} \cdot\right.$ Lei Jia $^{1}$
}

Published online: 5 October 2021

(c) The Author(s) 2021

\section{Correction to: \\ Aerospace Systems (2021) 4:29-36 https://doi.org/10.1007/s42401-020-00070-x}

The article 'Spatio-temporal graph convolutional neural network for remaining useful life estimation of aircraft engines', written by Mengni Wang, Yuanxiang Li, Yuxuan Zhang and Lei Jia, was originally published electronically on the publisher's internet portal on 17 November 2020 without open access. With the author(s)' decision to opt for Open Choice the copyright of the article changed on 17 of September 2021 to () The Author(s), 2021 and the article is forthwith distributed under a Creative Commons Attribution 4.0 International License, which permits use, sharing, adaptation, distribution and reproduction in any medium or format, as long as you give appropriate credit to the original author(s) and the source, provide a link to the Creative Commons licence, and indicate if changes were made. The images or other third party material in this article are included in the article's Creative Commons licence, unless indicated otherwise in a credit line to the material. If material is not included in the article's Creative Commons licence and your intended use is not permitted by statutory regulation or exceeds the permitted use, you will need to obtain permission directly from the copyright holder. To view a copy of this licence, visit http://creativecommons.org/licenses/by/4.0.

The original article has been corrected.

Open Access This article is licensed under a Creative Commons Attribution 4.0 International License, which permits use, sharing, adaptation, distribution and reproduction in any medium or format, as long as you give appropriate credit to the original author(s) and the source, provide a link to the Creative Commons licence, and indicate if changes were made. The images or other third party material in this article are included in the article's Creative Commons licence, unless indicated otherwise in a credit line to the material. If material is not included in the article's Creative Commons licence and your intended use is not permitted by statutory regulation or exceeds the permitted use, you will need to obtain permission directly from the copyright holder. To view a copy of this licence, visit http://creativecomm ons.org/licenses/by/4.0/.
The original article can be found online at https://doi.org/10.1007/s42 401-020-00070-x.

Yuanxiang Li

yuanxli@sjtu.edu.cn

Mengni Wang

moniwong@sjtu.edu.cn

Yuxuan Zhang

yuxuanzhang@sjtu.edu.cn

Lei Jia

westjia@sjtu.edu.cn

1 School of Aeronautics and Astronautics, Shanghai Jiao Tong University, Shanghai 200240, China 